Jurnal Kesmas Asclepius

Volume 1, Nomor 2, Desember 2019

e-ISSN: 2684-8287

p-ISSN: 2656-8926

DOI: https://doi.org/10.31539/jka.v1i2.580

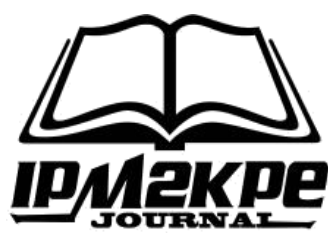

\title{
HUBUNGAN LINGKUNGAN PENGASUHAN DAN PEKERJAAN IBU TERHADAP PERKEMBANGAN BAYI 6-12 BULAN
}

\author{
Sara Herlina \\ Universitas Abdurrab \\ sara.herlina@univrab.ac.id
}

\begin{abstract}
ABSTRAK
Tujuan penelitian ini adalah untuk mengetahui hubungan lingkungan pengasuhan dan pekerjaan ibu terhadap perkembangan bayi. Desain penelitian ini adalah cross sectional. Hasil penelitian diperoleh mayoritas lingkungan pengasuhan baik sebanyak 39,7\%, ibu tidak bekerja sebanyak $60,9 \%$, dan bayi mengalami perkembangan normal sebanyak $52,3 \%$. Hasil uji chi square hubungan antara lingkungan pengasuhan terhadap perkembangan bayi diperoleh nilai $\mathrm{p}$ value $<0,005$ yaitu $<0,000$ hubungan antara pekerjaan ibu terhadap perkembangan bayi diperoleh nilai p value $<0,005$ yaitu 0,003 . Simpulan, terdapat hubungan antara lingkungan pengasuhan dan pekerjaan ibu terhadap perkembangan bayi.
\end{abstract}

Kata Kunci: Lingkungan Pengasuhan, Pekerjaan Ibu, Perkembangan

\section{ABSTRACT}

The purpose of this study was to determine the relationship between the caregiving environment and mother's work on infant development. The design of this study was cross sectional. The results of the study were obtained by the majority of good care environment as much as 39.7\%, mothers did not work as much as $60.9 \%$, and babies experienced normal development as much as 52.3\%. Chi square test results of the relationship between the caregiving environment for infant development obtained $p$ value $<0.005$, that is $<0,000$ the relationship between maternal work and infant development obtained $p$ value $<0.005,0.003$. Conclusion, there is a relationship between the care environment and mother's work on the development of the baby.

Keywords: Caregiving Environment, Mother's Work, Development

\section{PENDAHULUAN}

Anak merupakan generasi penerus suatu bangsa, dengan demikian dibutuhkan anak dengan kualitas yang baik agar tercapai masa depan bangsa yang baik. Untuk mendapatkan kualitas anak yang baik, maka harus dipastikan bahwa tumbuh dan kembang anak juga baik (Soetjiningsih, 2014; Moersintowati, 2008). Perkembangan (development) merupakan bertambahnya kemampuan (skill) dalam struktur dan fungsi tubuh yang lebih kompleks melalui pola yang teratur dan dapat diramalkan sebagai hasil dari proses pematangan. Tahap ini menyangkut adanya proses diferensiasi sel-sel tubuh, jaringan tubuh, organ-organ, dan sistem organ yang berkembang sedemikian rupa, sehingga masing-masing dapat memenuhi fungsinya. Cakupan tahap ini termasuk juga 
perkembangan emosi, intelektual dan tingkah laku sebagai hasil dari interaksi terhadap lingkungan (Sulistiawati, 2014).

Perkembangan anak yang baik memerlukan stimulasi yang baik dari orangtua. Orangtua pun wajib mengetahui berbagai aspek perkembangan yang dialami oleh anak pada berbagai rentang usia. Orangtua sebaiknya juga penting mengetahui dan memahami bagaimana pemeriksaan dan stimulasi dini tumbuh kembang pada anak mereka, sehingga setiap keterlambatan yang terjadi pada anak dapat dideteksi dan di stimulasi dengan cepat (Padila et al., 2019).

Masa bayi dan masa anak dini (usia 0- 3 tahun) terjadi perkembangan bayi sesuai dengan lingkungan yang mepengaruhinya dan juga terjadi perkembangan yang cepat dalam aspek sifat, sikap, minat, dan cara penyesuaian dengan lingkungan (Depkes, 2007). Skrining perkembangan untuk deteksi dini pada setiap anak penting dilakukan, terutama pada anak sampai usia 1 tahun agar bila ditemukan kecurigaan penyimpangan perkembangan dapat segera dilakukan intervensi dini sebelum terjadi kelainan. Dari beberapa sumber kepustakaan didapatkan bahwa intervensi pada anak dengan kecurigaan penyimpangan perkembangan sebaiknya dilakukan sebelum usia 3 tahun. Usia 9 bulan merupakan salah satu usia yang termasuk dalam jadwal skrining perkembangan (Fida, 2012).

Golden age berada pada masa kanak-kanak antara usia 1-6 tahun, usia ini merupakan masa yang sangat penting bagi pertumbuhan dan perkembangan individu. Perkembangan merupakan suatu proses bertambahnya struktur, fungsi, dan kemampuan manusia yang lebih kompleks dalam pola yang teratur, sebagai hasil dari proses pematangan (Sulistiawati, 2014). Sama seperti pernyataan dari (Soetjiningsih \& Ranuh, 2015) yang menyatakan bahwa masa lima tahun pertama kehidupan merupakan masa yang sangat peka terhadap lingkungan dan masa ini berlangsung sangat pendek dan tidak bisa diulang kembali, masa ini sering juga disebut masa keemasan (golden period), jendela kesempatan (window of opportunity) dan masa kritis (Rahardjo et al., 2019). Masa kanak-kanak memberi pengaruh yang besar pada individu dalam tahapan perkembangan selanjutnya. Anak toodler adalah anak yang berusia 1-3 tahun, yang pada umumnya kelompok anak tersebut sudah belajar percaya pada orang lain, mulai cepat meniru dan mengembangkan kemandirian membuka dan memakai baju, berjalan, mengambil, makan sendiri dan ke toilet mulai terbentuk kontrol diri. Jika perkembangan kemandirian toodler tidak didukung oleh orangtua, maka rerata anak akan memiliki kepribadian yang ragu-ragu dan jika anak dibuat merasa buruk pada saat kegiatan stimulasi ia melakukan kegagalan, maka anak akan menjadi pemalu dan pendiam (Lestari \& Hati, 2016; Padila et al., 2019).

Kualitas generasi penerus bangsa tergantung dari kualitas tumbuh kembang anak, terutama usia toodler (1-3) tahun, dimana anak menunjukkan perkembangan otak yang sangat signifikan, keluarga harus mengupayakan agar anaknya dapat bertumbuh dan berkembang secara optimal untuk mengindari tumbuh kembang yang abnormal, meragukan ataupun menyimpang. Penyimpangan tumbuh kembang harus dideteksi (ditemukan) sejak dini, terutama sebelum berumur 3 tahun, supaya dapat segera di intervensi (diperbaiki), bila deteksi terlambat, maka penanganan terlambat, sehingga penyimpangan sukar untuk diperbaiki (Cecily et al., 2009). Masa anak dianggap sebagai fase yang penting karena akan menentukan kualitas kesehatan, kesejahteraan, pembelajaran, dan perilaku dimasa yang akan datang serta masa depan masyarakat tergantung pada anak-anak yang mampu mencapai pertumbuhan dan perkembangan yang optimal (WHO, 2017). 
Hasil Survei Demografi Kesehatan Indonesia (SDKI) tahun 2012 menunjukkan jumlah anak usia dini (0-6 tahun) sebanyak 26,1 juta, sekitar 14,1 persen dari jumlah anak tersebut mengalami keterlambatan perkembangan (Riskesdas, 2013). Hasil penelitian Sarlis (2015) di Wilayah Kerja Puskesmas Garuda menunjukkan bayi usia enam bulan yang mengalami keterlambatan perkembangan sebanyak 21 persen.

Upaya pemeliharaan kesehatan anak ditujukan untuk mempersiapkan generasi akan datang yang sehat, cerdas dan berkualitas serta untuk menurunkan angka kematian anak yang dilakukan sejak janin masih dalam kandungan, dilahirkan, setelah dilahirkan, dan sampai berusia 18 tahun (Rivanica et al., 2016). Salah satu upaya penjaringan yang dilaksanakan secara komprehensif untuk mengetahui adanya penyimpangan pada tumbuh kembang anak serta untuk mengoreksi adanya faktor resiko adalah dengan deteksi dini. Dengan adanya faktor resiko yang telah diketahui, maka upaya untuk meminimalkan dampak pada anak bisa dicegah. Upaya tersebut diberikan sesuai dengan umur perkembangan anak. Dengan demikian dapat tercapai kondisi tumbuh kembang yang optimal. Untuk mencapai tujuan tersebut, maka sejak awal keadaan pertumbuhan dan perkembangan anak harus dipantau, sehingga bila ada gangguan atau penyimpangan dapat ditangani dengan benar. Untuk melakukan deteksi dini diperlukan suatu intrumen untuk mengetahui apakah anak telah bertumbuh dan berkembang secara normal (Nursalam \& Sri, 2013).

Tumbuh kembang anak juga dipengaruhi oleh lingkungan yang bersifat sementara maupun permanen serta dapat mempengaruhi kecepatan kualitas tumbuh kembang anak. Lingkungan di sekitar anak merupakan potensi risiko terhadap tumbuh kembang anak (Soetjiningsih, 2015). Lingkungan pengasuhan adalah praktik- praktik pengasuhan dan segala interaksi yang terjadi antara orangtua dan anak, tercakup tugas pengasuhan secara umum dan pola asuh makan (Depkes, 2007). Pengasuhan yang diperlukan agar fisik anak tumbuh dengan baik adalah menyediakan konsumsi gizi yang cukup kepada anak (pemberian ASI, makanan pendamping dan makanan sapihan), melindungi anak dari penyakit infeksi (menyangkut upaya pemeliharaan kebersihan tubuh, rumah, tempat bermain dan alat-alat yang berhubungan dengan makanan), melindungi gejala dini dan lanjut dari gangguan kesehatan (secara preventif dan kuratif). Sehingga pertumbuhan anak menjadi lebih baik dengan adanya pola pengasuhan makan yang meliputi merencanakan makan, menyiapkan makanan, menyuapi, memonitor jadwal makan, peralataan makan, cara dan situasi pemberian makan, perkenalan makanan baru, sikap ibu bila anak menghabiskan makanan atau tidak serta anak mendapatkan gizi yang baik (Soetjiningsih, 2014).

Pekerjaan ibu juga berpengaruh terhadap perkembangan anak. Ibu bekerja dapat memberikan dampak negatif maupun positif terhadap perkembangan anak. Dampak negatif dari ibu bekerja adalah, kehadiran ibu dalam kehidupan sehari-hari sang anak lebih sedikit dibandingkan dengan ibu yang tidak bekerja, sehingga kesempatan ibu untuk memberikan motivasi dan stimulasi dalam anak melakukan tugas- tugas perkembangan motorik terbatas. Dampak positif dari ibu bekerja terhadap perkembangan anak dapat dilihat dari efek yang didapat apabila anak dititipkan di tempat penitipan anak yang memperkerjakan pengasuh terlatih. Anak memiliki interaksi sosial yang baik, perkembangan kognitif yang pesat, serta fisik yang lebih aktif jika dibandingkan dengan anak yang hanya berada di rumah bersama ibunya yang tidak bekerja (Purnama et al., 2012). Hasil penelitian Yuliasri et al., (2015) menunjukkan hasil uji mann whitney test menunjukkan nilai Asymp. Sig. (2-tailed) $<0,05(0,00<$ 0,05). Hasil uji menunjukkan bahwa $\mathrm{H \alpha}$ diterima yang diartikan bahwa terdapat 
perbedaan antara ibu bekerja dan tidak bekerja terhadap perkembangan anak di TPA Ar- Raihan Bantul. perkembangan bayi 6-12 bulan di wilayah kerja puskesmas simpang baru kota pekanbaru.

\section{METODE PENELITIAN}

Jenis penelitian yang digunakan dalam penelitian ini adalah analitik kuantitatif dengan desain cross-sectional study. Sampel dalam penelitian ini adalah bayi yang berusia 6-12 bulan yang tinggal di Wilayah Kerja Puskesmas Simpang Baru Kota Pekanbaru yang berjumlah 151 bayi. Pengambilan sampel dilakukan dengan teknik systematic random sampling. Dengan prosedur ini disusun pula kerangka sampel yang terdiri atas unit penelitian dengan nomor urut tertentu. Teknik pengumpulan data menggunakan kuesioner dan intervensi langsung untuk mengukur perkembangan bayi. Data yang digunakan data primer. Pengolahan data dilakukan dalam tahap-tahap editing, coding, processing, cleaning dan tabulating. Analisis data dilakukan secara univariat dan bivariat dengan uji chi square.

\section{HASIL PENELITIAN \\ Hasil penelitian Analisa Univariat}

Tabel. 1

Distribusi Perkembangan Bayi 6-12 Bulan

\begin{tabular}{|c|c|c|}
\hline \multirow{2}{*}{ Variabel } & \multicolumn{2}{|c|}{ Jumlah } \\
\hline & $(n=151)$ & $100 \%$ \\
\hline \multicolumn{3}{|l|}{ Lingkungan Pengasuhan } \\
\hline Kurang & 32 & 21,2 \\
\hline Cukup & 59 & 39,1 \\
\hline Baik & 60 & 39,7 \\
\hline \multicolumn{3}{|l|}{ Pekerjaan Ibu } \\
\hline Bekerja & 59 & 39,1 \\
\hline Tidak Bekerja & 92 & 60,9 \\
\hline \multicolumn{3}{|l|}{ Perkembangan } \\
\hline Terlambat & 72 & 47,7 \\
\hline Normal & 79 & 52,3 \\
\hline
\end{tabular}

Data dari Dinas Kesehatan Kota Pekanbaru tahun 2014 terdapat keterlambatan perkembangan sebanyak 38 orang (2,16 persen). Peneliti juga melakukan survei pendahuluan dengan melakukan pemeriksaan perkembangan terhadap 50 orang bayi yang berusia 6-12 bulan di Wilayah Kerja Puskesmas Simpang Baru, dari 50 bayi terdapat 30 bayi (60,0 persen) yang mengalami keterlambatan perkembangan sebanyak 11 bayi (36,6 persen) dan 20 bayi (40,0 persen) yang tidak mengalami keterlambatan perkembangan. Berdasarkan analisis univariat pada tabel 1 menunjukkan bahwa dari 151 responden terdapat 39,7 persen lingkungan pengasuhan baik, mayoritas ibu tidak bekerja sebanyak 60,9 persen, mayoritos bayi perkembangannya normal sebanyak 52,3 persen. 


\section{Analisa Bivariat}

Tabel. 2

Hubungan Lingkungan Pengasuhan terhadap Perkembangan Bayi 6-12 Bulan

\begin{tabular}{|c|c|c|c|c|c|c|c|}
\hline \multirow{3}{*}{$\begin{array}{l}\text { Variabel Independen } \\
\text { dan Kategori }\end{array}$} & \multicolumn{4}{|c|}{$\underline{\text { Perkembangan Bayi }}$} & \multicolumn{2}{|c|}{ Jumlah } & \multirow{3}{*}{ Pvalue } \\
\hline & Terlambat & & Norma & & $\mathrm{n}$ & $\%$ & \\
\hline & $\mathrm{n}$ & $\%$ & $\mathrm{n}$ & $\%$ & & & \\
\hline \multicolumn{8}{|c|}{ Lingkungan Pengasuhan } \\
\hline Kurang & 23 & 71,9 & 9 & 28,1 & 32 & 100 & \multirow{3}{*}{$<0,000$} \\
\hline Cukup & 32 & 54,2 & 27 & 45,8 & 59 & 100 & \\
\hline Baik & 17 & 28,3 & 43 & 71,7 & 60 & 100 & \\
\hline
\end{tabular}

Berdasarkan tabel 2, dapat dilihat bahwa lingkungan pengasuhan yang cukup bayi mengalami keterlambatan sebanyak 32 orang (54,2\%), sedangkan lingkungan pengasuhan yang baik bayi mengalami perkembangan normal sebanyak 43 orang $(71,7 \%)$. Hasil uji statistik dengan menggunakan uji chi square diperoleh $P$ value $<0,005$ yaitu $<0,000$ yang artinya terdapat hubungan antara lingkungan pengasuhan terhadap perkembangan bayi.

Tabel. 3

Hubungan Pekerjaan Ibu

terhadap Perkembangan Bayi 6-12 Bulan

\begin{tabular}{lccccc}
\hline \multirow{1}{*}{ Variabel } & \multicolumn{3}{c}{ Perkembangan Bayi } & P Value \\
& $\mathrm{n}$ & $\%$ & $\mathrm{n}$ & $\%$ & \\
\hline Pekerjaan Ibu & & & & & \\
Bekerja & 37 & 62,7 & 35 & 38,3 & 0,003 \\
Tidak Bekerja & 22 & 37,3 & 57 & 62,0 & \\
\hline
\end{tabular}

Berdasarkan tabel 3, dapat dilihat bahwa ibu yang bekerja bayinya mengalami keterlambatan sebanyak 37 orang $(62,7 \%)$, sedangkan ibu yang tidak bekerja memiliki bayi dengan perkembangan normal sebanyak 57 orang $(62,0 \%)$. Hasil uji statistik dengan menggunakan uji chi square diperoleh $P$ value $<0,005$ yaitu 0,003 yang artinya terdapat hubungan antara pekerjaan ibu terhadap perkembangan bayi.

\section{PEMBAHASAN}

Berdasarkan hasil penelitian bahwa lingkungan pengasuhan yang cukup bayi mengalami keterlambatan sebanyak 32 orang (54,2\%), sedangkan lingkungan pengasuhan yang baik bayi mengalami perkembangan normal sebanyak 43orang (71,7\%). Menurut penelitian Dianita (2014) menunjukkan bahwa faktor lingkungan pengasuhan mempengaruhi pertumbuhan dan perkembangan pada balita, yaitu sebanyak 25 responden (89,3\%). Menurut teori Andriana (2011) mengatakan bahwa pada lingkungan pengasuhan interaksi ibu dan anak sangat mempengaruhi tumbuh kembang anak. Dalam hal ini antara teori dan praktik terdapat kesenjangan, dimana sebagian besar responden adalah sebagai ibu rumah tangga yang seharusnya mempunyai interaksi yang baik dengan balita, tetapi orangtua dalam mengasuh cenderung membiarkan balita bermain sendiri dengan temannya tanpa adanya pengawasan dari orangtua dan menitipkan balita kepada orang yang tinggal dalam satu rumah atau 
neneknya ketika ibu melakukan aktifitas seperti memasak, mencuci dan lain-lain.

Hasil penelitian Gemala (2007) menunjukkan bahwa ada hubungan antara status pekerjaan ibu dengan perkembangan anak usia 6-24 bulan dengan nilai Odd Ratio (OR) yang diperoleh sebanyak 4,7 yang menunjukkan ibu yang bekerja berpeluang 4,7 kali mengalami gangguan perkembangan pada anak.

Rachmaniah (2014) menyatakan bahwa terdapat hubungan bermakna antara tingkat pengetahuan ibu tentang ASI dengan tindakan ASI eksklusif. Peneliti lain melaporkan bahwa terdapat hubungan yang bermakna antara tingkat pendidikan ibu dengan sikap pemberian ASI ekslusif di wilayah Puskesmas Kartasura Kabupaten Sukoharjo (Sutrisno, 2015).

Masalah status gizi pada anak di Indonesia masih menjadi fokus utama dalam upaya perbaikan gizi masyarakat. Global Nutrition Report (GNR) tahun 2014 menunjukkan Indonesia termasuk dalam 17 negara, diantara 117 negara, yang mempunyai tiga masalah gizi yaitu stunting, wasting dan overweight pada bayi atau balita. Menurut hasil Pemantauan Status Gizi (PSG) 2015, sebesar 29\% balita di Indonesia termasuk kategori pendek (Anuraga, 2016). Fakta lain menyatakan Indonesia menduduki peringkat lima besar masalah stunting di dunia. Upaya intervensi untuk mencegah bayi atau balita dari stunting dapat dilakukan pada 1000 Hari Pertama Kehidupan (HPK) (Kemenkes, 2016).

Bayi juga tidak dianjurkan untuk diberi makanan tambahan lainnya seperti sayur dan buah. Hanindita dalam Sukmasari (2016) menyatakan bahwa tubuh bayi belum memiliki protein pencernaan yang lengkap. Berbagai enzim seperti amylase atau enzim yang diproduksi pankreas belum cukup ketika bayi belum berusia 6 bulan. Begitu pula dengan enzim pencerna karbohidrat seperti maltase serta sukrase, dan lipase serta bile salts yang berfungsi untuk mencerna lemak. Apabila memberi bayi makanan selain ASI sebelum usia 6 bulan tanpa ada indikasi tertentu, ada kondisi paling gawat yang bisa terjadi yaitu invaginasi atau intususepsi dan gangguan pencernaan lainnya. MPASI dini dapat juga dapat meningkatkan risiko anak alergi dan terkena berbagai penyakit. Hal ini dikarenakan saat bayi menerima asupan lain selain ASI, maka kekebalan yang diterima bayi akan berkurang. Pemberian MPASI dini juga berisiko masuknya berbagai jenis kuman karena makanan tidak bersih. Keadaan tersebut memungkinkan bayi akan sering terganggu kesehatannya sehingga tumbuh kembang bayi dapat terhambat dikemudian hari

Tumbuh kembang bayi penting untuk diperhatikan pada 1000 Hari Pertama Kelahiran (HPK). Pada saat ini bayi sedang berada dalam masa emas pertumbuhannya. Terhambatnya tumbuh kembang bayi disebabkan oleh asupan gizi yaitu ASI eksklusif, serta pola asuh dan stimulasi (Lisa, 2012; Fauziyah, 2015; Kholifah et al., 2014). Apabila pertumbuhan dan perkembangan ini terhambat, maka bayi dimungkinkan mengalami dampak buruk, baik jangka pendek ataupun jangka panjang (Depkes RI, 2014). Novita et al., (2008) menyatakan pemberian ASI non eksklusif mempunyai dampak panjang yaitu berpeluang terjadinya IQ di bawah rata-rata 1,68 kali lebih besar dibandingkan anak yang diberi ASI eksklusif. Pengenalan MPASI dini menyebabkan bayi mempunyai daya tahan tubuh yang rendah terhadap infeksi penyakit sehingga tumbuh kembangya dapat terhambat (Kemenkes, 2014). Sugihartono \& Nurjazuli (2012) juga menyatakan riwayat pemberian ASI berkaitan erat dengan kejadian pneumonia pada bayi. 
Setiap orang tua pasti berkeinginan agar anaknya dapat tumbuh dan berkembang secara optimal, yaitu anak tersebut dapat mencapai tahap pertumbuhan dan perkembangan yang baik sesuai dengan potensi genetik anak itu. Secara alamiah, pertumbuhan dan perkembangan setiap individu tidak sama dan akan mengalami tahapan yang sangat pesat selama hidupnya yaitu sejak masa embrio sampai sepanjang kehidupan mengalami perubahan kearah peningkatan baik secara ukuran maupun secara perkembangan. Dalam proses pertumbuhan dan perkembangan tersebut dapat dipengaruhi oleh faktor internal dan faktor eksternal. Dimana faktor eksternal lebih mempengaruhi dalam proses pertumbuhan dan perkembangan (Aziz, 2012).

Lingkungan pengasuhan adalah praktik-praktik pengasuhan dan segala interaksi yang terjadi antara orangtua dan anak, tercakup tugas pengasuhan secara umum dan pola asuh makan (Depkes, 2007). Pola pengasuhan pada usia ini bersifat dyadic, artinya interaksi secara langsung antara anak dan pengasuh. Ibu adalah pengasuh terbaik bagi anak, namun adanya variasi pengasuh dapat memperkaya pengalaman anak. Disamping itu yang lebih penting adalah pengasuhan yang aman (secure). Oleh karena itu pengasuhan yang paling baik adalah dilakukan oleh ibu sendiri dan ibu bersama ayah. Kaitannya dengan alokasi waktu ibu, disamping aspek kuantitas, perkembangan anak yang sehat juga ditentukan oleh kualitas pengasuhan yang diterima. Orangtua dituntut menyediakan waktu secara kuantitatif dengan memperhatikan kualitasnya, ibu dalam mengasuh perlu mempunyai sikap tanggap dan responsif terhadap anak, mempunyai pengetahuan, keterampilan tentang gizi, kesehatan, pengasuhan dan mengenal konsep perkembangan anak.

Dalam proses pengasuhan tersebut terdapat interaksi antara ibu dan anak. Adanya interaksi antara ibu dan anak dalam jangka panjang akan mempengaruhi status gizi dan tumbuh kembang anak. Anak perlu memperoleh perangsangan (stimulasi) untuk mencapai tingkat perkembangan optimal sesuai yang diharapkan. Kurangnya perangsangan untuk berkembang pada masa anak-anak dapat menyebabkan kelambatan dan gangguan perkembangan anak (Andriana, 2011).

Perkembangan anak juga sangat dipengaruhi oleh tingkat stimulasi yang diberikan pada anak. Semakin sering anak memperoleh stimulisi, maka semakin cepat anak belajar dan meningkatkan kemampuan serta menyelesaikan tugas perkembangannya. Penting bagi orangtua memahami setiap tugas perkembangan anaknya di berbagai rentang usia dari 0 tahun hingga usia 6 tahun (Padila et al., 2019).

Lingkungan pengasuhan yang baik akan mempengaruhi perkembangan bayi. Bayi dengan lingkungan pengasuhan yang baik akan mengalami perkembangan yang normal bila dibandingkan dengan bayi yang lingkungan pengasuhannya kurang akan mengalami keterlambatan perkembangan.

Berdasarkan hasil penelitian bahwa pekerjaan ibu juga berhubungan dengan perkembangan anak dimana ibu yang bekerja bayinya mengalami keterlambatan sebanyak 37 orang $(62,7 \%)$, sedangkan ibu yang tidak bekerja memiliki bayi dengan perkembangan normal sebanyak 57 orang $(62,0 \%)$.

Menurut Encyclopedia of Children's Health dalam Purnama et al., (2012) ibu bekerja adalah seorang ibu yang bekerja di luar rumah untuk mendapatkan penghasilan, selain membesarkan dan mengurus anak di rumah. Ibu yang sepenuhnya melakukan tugas-tugas rumah tangga dan mengurus keluarga termasuk ibu tidak bekerja.

Bekerja umumnya merupakan kegiatan yang menyita waktu untuk menunjang kehidupan dalam keluarga dimana ibu rumah tangga akan memiliki waktu yang lebih maksimal sehingga dapat mengetahui segala aktifitas anaknya. Orangtua yang tidak 
bekerja dapat memberikan stimulasi dengan baik karena ibu mempunyai banyak waktu untuk merawat bayinya termasuk memberikan stimulasi dengan frekuensi yang lebih intensif (Nursalam, 2005).

Namun yang menjadi permasalahan terkadang pengetahuan orangtua mengenai status perkembangan anak sangat minim, bahkan banyak orangtua yang tidak mengetahui dengan pasti tugas perkembangan anak sesuai usianya (Padila et al., 2019).

\section{SIMPULAN}

Berdasarkan analisa univariat mayoritas lingkungan pengasuhan baik, mayoritas ibu tidak bekerja dan bayi mengalami perkembangan normal. Berdasarkan uji statistik hubungan antara lingkungan pengasuhan terhadap perkembangan bayi menunjukkan terdapat hubungan antara lingkungan pengasuhan terhadap perkembangan bayi dan terdapat hubungan antara pekerjaan ibu terhadap perkembangan bayi.

\section{SARAN}

Diharapkan bagi ibu untuk meningkatkan pengetahuan dengan selalu mengikuti penyuluhan-penyuluhan tentang kesehatan khususnya status gizi balita, begitu juga bagi tenaga kesehatan lebih meningkatkan lagi konseling terhadap keluarga, penyuluhanpenyuluhan kesehatan, serta meningkaykan pelayanan kesehatan.

\section{DAFTAR PUSTAKA}

Andriana, D. (2011) Tumbuh Kembang dan Terapi Bermain pada Anak. Jakarta: Salemba Medika

Anuraga, A. L. (2016). Stunting, Prioritas Utama Masalah Gizi Indonesia. (Online), (http://www.cnnindonesia.com/gaya- 255111943/stunting-prioritas-utama-masalah-gizi-indonesial

Aziz, A. (2012) Pengantar Ilmu Keperawatan Anak I. Jakarta: Salemba Medika

Cecily, L., Betz, B., \& Showden, L. A. (2009). Buku Saku Keperawatan Pediatri (5th ed.). Jakarta: EGC

Depkes, RI. (2007). Pedoman Pelaksanaan Stimulasi Deteksi dan Intervensi Dini Tumbuh Kembang Anak Ditingkat Pelayanan Dasar. Jakarta: Departeman Kesehatan Republik Indonesia

Depkes, RI. (2014). Orangtua Kunci Utama Tumbuh Kembang Anak" (Online), (http://www.depkes.go.id/article/view/201408120001/orang-tua- kunci-utamatumbuh-kembang-anak.html

Dianita, P. D. (2014) Studi tentang Faktor-Faktor yang Mempengaruhi Pertumbuhan dan Perkembangan pada Balita di Desa Pengalan RW 03 Menganti Gresik. STikes Wiliam Booth Surabaya

Fauziyah, Y. (2015). Hubungan antara Status Pemberian ASI dengan Perkembangan Motorik Kasar pada Bayi Usia 7-12 Bulan di Desa Tohudan Kecamatan Colomadu Kabupaten Karanganyar. Universitas Muhammadiyah Surakarta

Fida, M. (2012). Pola Pertumbuhan dan Perkembangan. Pengantar Ilmu Kesehatan Anak. Yogyakarta: DMedika

Gemala, D. (2007). Perkembangan Anak Usia 6-24 Bulan di Wilayah Kerja Puskesmas Andalas Kecamatan Padang Timur Padang. Kesehatan Masyarakat, 3(1)

Kemenkes, RI. (2014). Infodatin Situasi dan Analisis ASI Eksklusif. Jakarta Selatan: Kementrian Kesehatan RI 
Kemenkes, RI. (2016). Infodatin Situasi Balita Pendek. Jakarta Selatan: Kementrian Keehatan RI

Kholifah, N. S., Fadillah, N., As'ari, H., \& Hidayart, T. (2014). Perkembangan Motorik Kasar Bayi melalui Stimulasi Ibu di Kelurahan Kemayoran Surabaya. Jurnal Sumber Daya Manusia Kesehatan. Jurnal Sumber Daya Manusia Kesehatan, 1(1), 120-121

Lestari, P., \& Hati, F. S. (2016). Pengaruh Pemberian Stimulasi pada Perkembangan Anak Usia 12-36 The Influence of Stimulation in Children Aged 12-36 Months in Sedayu Regency, Bantul. Jurnal Ners dan Kebidanan Indonesia, 4(1), 44-48. https://doi.org/http://dx.doi.org/10.21927/jnki

Lisa, U. F. (2012). Hubungan Pemberian ASI Eksklusif dengan Perkembangan Motorik Kasar Balita di Kelurahan Brontokusuman Kecamatan Mergangsan Yogyakarta. Jurnal Ilmiah STIKES U'Budiyah, 1(2), 37

Moersintowati, M. (2008) Deteksi Dini Tumbuh Kembang. Simposium Penatalaksanaan Mutakhir Bidang Ilmu Kesehatan Anak untuk Mencapai Tumbuh Kembang Optimal. Bandung: IDAI Jawa Barat

Novita, L., Gurnida, D. A., \& Garna, H. (2008). Perbandingan Fungsi Kognitif Bayi Usia 6 Bulan yang Mendapat dan yang Tidak Mendapat ASI Eksklusif. Sari Pediatri, 9(6), 432-433

Nursalam, D. (2005) Asuhan Keperawatan Bayi dan Anak. Jakarta: Salemba Medika

Nursalam, R. S., \& Sri, S. (2013). Asuhan Keperawatan Bayi dan Anak untuk Perawat dan Bidan. Jakarta: Salemba Medika

Padila, P., Andari, F. N., Harsismanto, J., Andri, J. (2019). Tumbuh Kembang Anak Usia Toddler Berbasis Research. Lubuklinggau: ASRA

Padila, P., Andari, F, N., Andri, J. (2019). Hasil Skrining Perkembangan Anak Usia Toddler antara DDST dengan SDIDTK. Jurnal Keperawatan Silampari, 3(1), 244-256. https://doi.org/https://doi.org/10.31539/jks.v3i1.809

Purnama, U., Ali, M., \& Tjipta, G. D. (2012) Hubungan antara Status Ibu Bekerja atau Ibu Tidak Bekerja dengan Status Gizi Anak Balita di Kecamatan Medan Tembung. Universitas Sumatera Utara

Rachmaniah, N. (2014). Hubungan Tingkat Pengetahuan Ibu tentang ASI dengan Tindakan Asi Eksklusif. Universitas Muhammadiyah Surakarta

Rahardjo, S., Wayanti, S., \& Wardani, N. E. K. (2019). Pengaruh Fungsi Manajemen Pelaksana Kegiatan SDITK terhadap Cakupan SDITK Balita \& Anak Prasekolah. Jurnal Pamator, 12(1). https://doi.org/http://dx.doi.org/10.21107/pmt.v12i1.5173

Rivanica, R., Rhipiduri, R., \& Oxyandi, M. (2016). Buku Ajar Deteksi Dini Tumbuh Kembang dan Pemeriksaan Bayi Baru Lahir. Jakarta: Salemba Medika

Sarlis, N. (2015) Stimulasi Dini terhadap Perkembangan Bayi Usia Enam Bulan di Wilayah Kerja Puskesmas Garuda Pekanbaru Tahun 2015. STIKES Hangtuah

Soetjiningsih, S. (2014). Tumbuh Kembang Anak. Jakarta: EGC

Soetjiningsih, S., \& Ranuh, I. (2015). Tumbuh Kembang Anak. Jakarta: EGC

Sugihartono, S,. \& Nurjazuli, N. (2012). Analisis Faktor Risiko Kejadian Pneumonia pada Balita di Wilayah Kerja Puskesmas Sidorejo Kota Pagar Alam. Jurnal Kesehatan Lingkungan Indonesia, 11(1), 85-86

Sukmasari, R. N. (2016). Ini Efeknya Jika Tanpa Saran Dokter MPASI Diberi Sebelum Anak Usia 6 Bulan (https://health.detik.com/read/2016/05/20/100059/3214248/1300/iniefekny a-jikatanpa-saran-dokter-mpasi-diberi-sebelum-anak-usia-6-bulan 
Sulistiawati, A. (2014) Deteksi Tumbuh Kembang Anak. Jakarta: Salemba Medika

Sutrisno, S. (2015). Hubungan Tingkat Pendidikan Ibu dengan Sikap Pemberian ASI Eksklusif di Wilayah Puskesmas Kartasura Kabupaten Sukoharjo. Universitas Muhammadiyah Surakarta

WHO. (2017). Early Child Development. Retrieved from https://www.tandfonline.com/loi/gecd20?open=187\&year=2017\&repitition=0\#vol 187_2017

Yuliasri, T. R., Nugraheny, E., \& Atika, A. (2015). Perbedaan Ibu Bekerja dan Tidak Bakerja terhadap Perkembangan Anak. Akademi kebidanan Ummi Khasana 